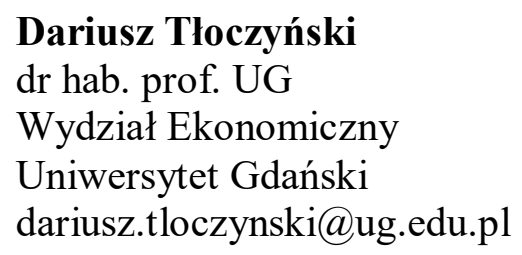

DOI: $10.35117 /$ A_ENG_17_02_06

\title{
Competitiveness of the air transport sector as a determinant of the development of time and road accessibility to airports
}

\begin{abstract}
Air transport is an important element in the development of every country. Aviation impact on economic development, and the economy has an impact on air transport. This relationship has an impact on entities operating on the market for air transport services. Air carriers, airports want to achieve maximize their operational and financial data.

In Poland, most airports shareholders are the public authorities, which support the development of airports. Public institutions involved directly and indirectly. Indirect, because the building communication system to airports, modernizing rail and road infrastructure. The dynamic development of this infrastructure has resulted to an increase in catchement area. Air transport companies realize specific development strategies, they are forced to take measures to increase competitiveness. Most often this is done by intangible factors.
\end{abstract}

Keywords: air transport companies, potential competitive air transport, airports, system airport links

\section{Introduction}

Air transport plays a very important role in the economy of every country. On the one hand it affects economic development, and on the other hand, itself is subject to market changes. This dependency affects the operators of the air transport services market. Carriers, airports strive to maximize their operational and financial data.

In Poland, most of the airports are owned by the public authorities, which support the development of airports. In addition to direct involvement in the operation of air traffic management operators, indirect forms are also indicated. construction of a communication system for airports, construction of railway and road infrastructure. The dynamic development of the identified infrastructure has led to an increase in the impact of the airport, so-called catchment area.

Entities operating implementing specific development strategies are forced to take measures to increase competitiveness. This is usually done by intangible factors.

For the purposes of the work, an analysis of the available literature on the subject was made using the descriptive method. Conclusions from secondary data analysis were presented in the summary.

\section{Competitiveness potential}

Air transport companies operating in a competitive market are forced to pursue a specific strategy to achieve a competitive advantage in the market. The pursuit of specific goals is based on internal and external factors. Bossak points out that internal factors can be: reduction of unit costs and, consequently, the possibility of offering lower prices, higher quality and personalization of the product, implementation of product and technology innovations as well as organizational and management activities that increase production, sales and profitability, 
and growth in goodwill. On the other hand, the most important external factors include: economic situation, changes in the structure of demand and supply of society, technical and technological progress and changes in the competitive environment in the market.

Internal factors are the basis for determining the competitive potential of an enterprise. B. Godziszewski defines as a system of material and non-material resources, which allows the company to implement optimal instruments to compete effectively on the market. It can be referred to as "the total of material and non-material assets of the country, sector, industry or enterprise necessary to enable them to function in the competitive market." The result of competitively exploiting the competitive potential is to achieve a competitive advantage. The company builds a competitive advantage by using its resources, predispositions. The resources, rather than the environment, determine the ultimate "outcome of the market game".

The relationship between the company's resources and its competitive potential is shown in Table 1.

Tab. 1. Relationships between enterprise resources and their potential. Source: M.J. Stankiewicz, Konkurencyjność przedsiębiorstwa. Budowanie konkurencyjności przedsiębiorstwa w warunkach globalizacji, Towarzystwo Naukowe Organizacji i

Kierownictwa, Toruń 2002, p. 104.

\begin{tabular}{|l|l|}
\hline situation & meaning \\
\hline $\begin{array}{l}\text { resources }>\text { competitiveness } \\
\text { potential }\end{array}$ & $\begin{array}{l}\text { some of its resources cannot be effectively used by the } \\
\text { company to create competitiveness }\end{array}$ \\
\hline $\begin{array}{l}\text { resources=competitiveness } \\
\text { potential }\end{array}$ & $\begin{array}{l}\text { The company has such resources and the amount that it } \\
\text { needs to compete }\end{array}$ \\
\hline $\begin{array}{l}\text { resources }<\text { competitiveness } \\
\text { potential }\end{array}$ & $\begin{array}{l}\text { The company has less resources (quantity and quality) } \\
\text { than it is to compete effectively }\end{array}$ \\
\hline
\end{tabular}

Resources classified as competitiveness potential can be divided into two groups: material and non-material. The company's resource allocation is shown in Figure 1.

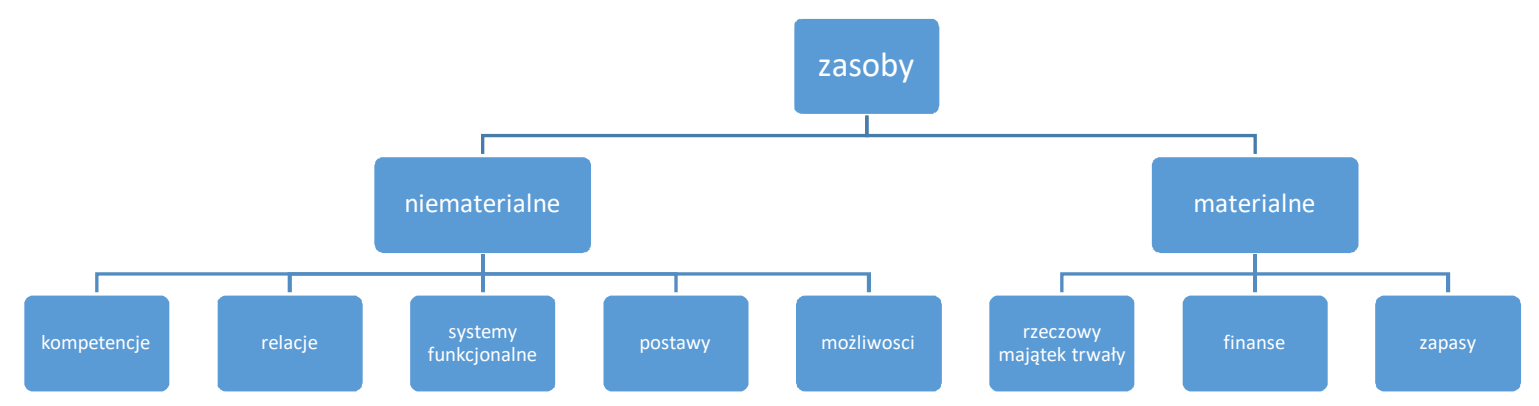

1. Systematization of enterprise resources. Source: M.J. Stankiewicz, Konkurencyjność przedsiębiorstwa. Budowanie konkurencyjności przedsiębiorstwa w warunkach globalizacji, Towarzystwo Naukowe Organizacji i Kierownictwa, Toruń 2002, p. 105.

Literature distinguishes nine functional-resource spheres, which create the potential of the company's competitiveness. Based on the analysis of the publication, the author of the article points out five key areas: innovation, production, marketing, financial policy, enterprise organization. The individual spheres consist of the resources and skills that constitute the so-called components of competitiveness potential. They influence the creation of competitive advantage and determine the implementation of the instruments of competition. 


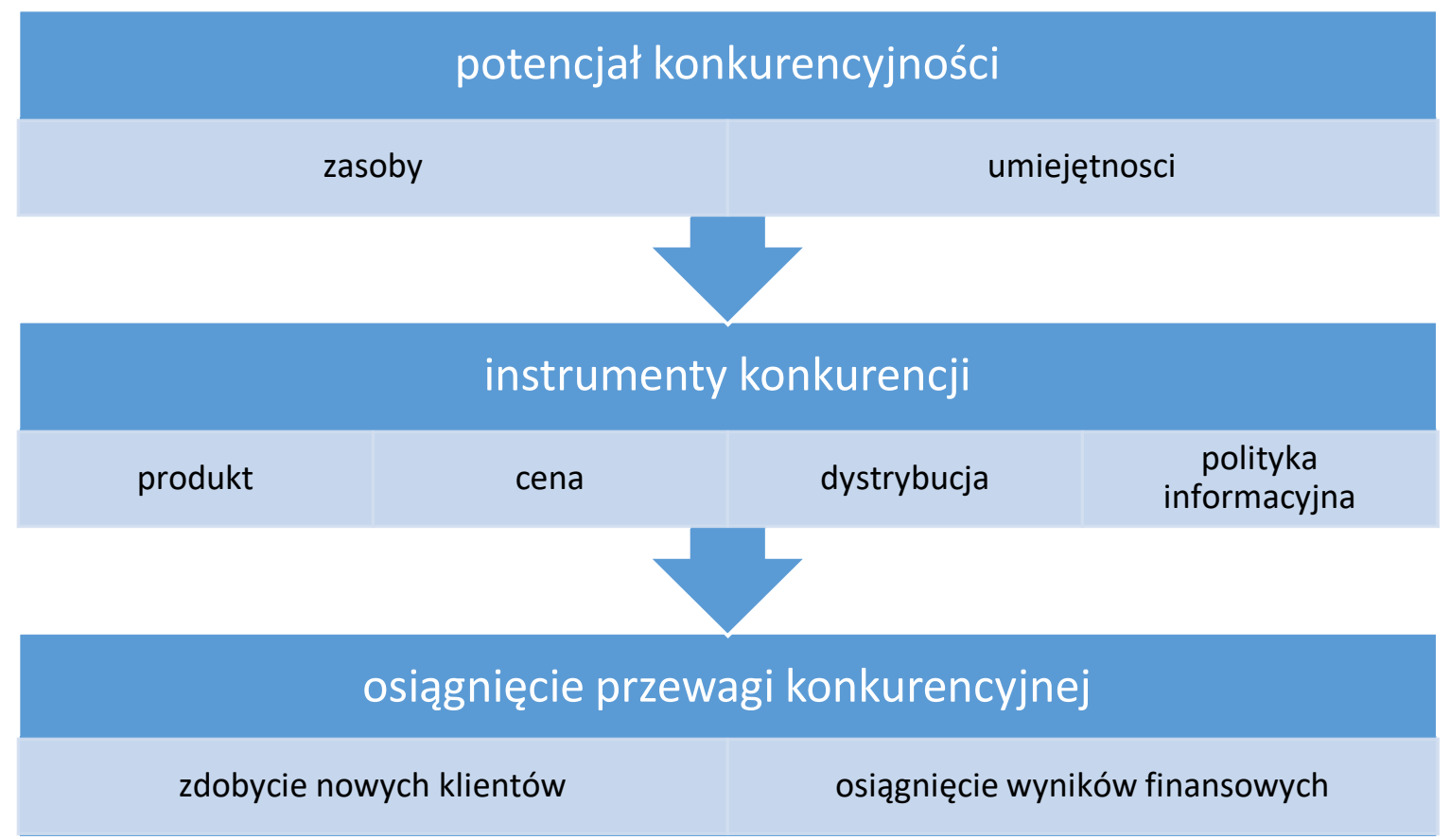

2. Impact of competitiveness potential on gaining competitive advantage. Source: own elaboration.

\section{Air transport as an element of economic development}

For many years there has been a connection between the air traffic and the level of economic development. As a rule, the dynamics of air transport growth is 3-4 percentage points higher than economic growth. The main factors determining the impact of air transport are:

- direct effects,

- indirect effects,

- induced effects,

- catalyst effects (economy spin) ${ }^{1}$.

ACI estimates that air transport generated around 60 million jobs in 2015 and around $3.4 \%$ of world GDP. Taking into account the above effects, the largest air traffic has an impact on employment in the following European countries: 1.4 million in Turkey, 1.3 million in Spain and 1.2 million in Germany. In Europe, its employment impact is estimated at 12 million jobs.

In Poland air transport generated over 440 thousand. jobs. Most in the sector of entities operating in the vicinity of airports. So airports are able to attract potential investors who want to locate their capital in the perimeter. Next to the airport are the business areas, hotels, the town of the so-called Airport City. On the other hand, the dynamics of air traffic development in the region is closely linked to the investment attractiveness of gminas and the size of GDP. Figure 3 analyzes regional airports with respect to air traffic in ports and GDP per capita in the municipality in which the airport is located. On the basis of the GDP figures per capita, Polish airports were assigned. The airport was shut down in Radom because of the insufficient number of passengers.

\footnotetext{
${ }^{1}$ Economic Impact of European Airports. A Critical Catalyst to Economic Growth. ACI Europe, styczeń 2015.
} 


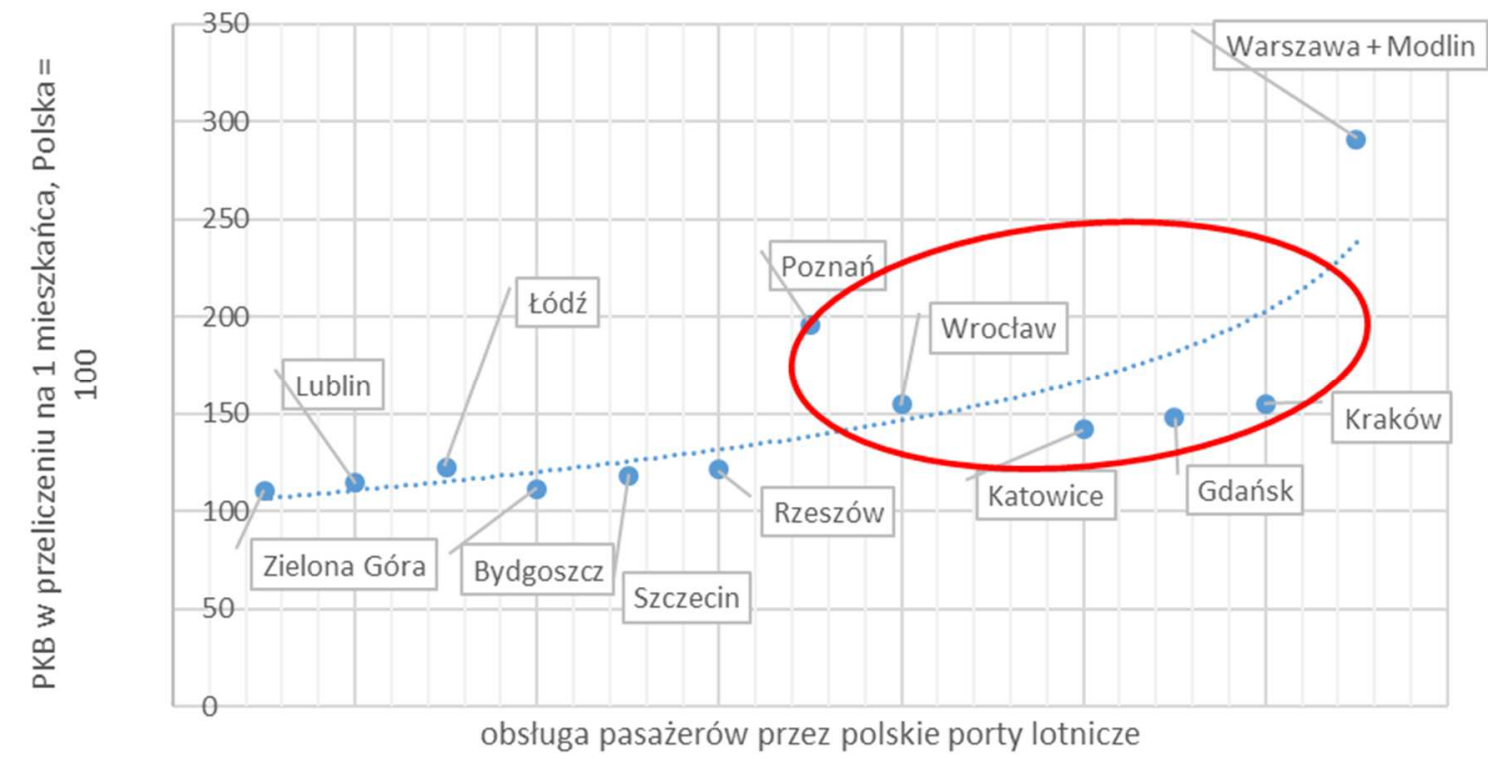

3. Dependence on passenger services by Polish airports and GDP per capita. Source: own elaboration based on: www.ulc.gov.pl (access: 15 July 2016) and report on Polish metropolises, PWC, Warszawa 2015, p. 5.

The top right corner is a strong duopoly and strong agglomeration. The airports in Warsaw and Modlin should be considered together because they operate one agglomeration, the gravity area is the same, and they are complementary to one another.

The second group comprises ports in Krakow, Gdansk, Katowice, Wroclaw and Poznan, each of these ports has serviced over 1.4 million passengers in 2015, while the ports are characterized by much higher per capita GDP than the last port group. (Rzeszow, Szczecin, Bydgoszcz, Lodz, Zielona Gora). Passenger traffic at these ports is much lower, with less than 1.0 million passengers. At the same time, the analyzed GDP is also lower than the large regional ports.

It should be noted that the economic potential of the region and the number of passengers served affect the competitive position of airports. When analyzing the relationship between air traffic volume and GDP per capita, the three main areas of competition:

- first, where the main competitors of Chopin Airport in Warsaw and Modlin Airport are regional ports.

- second competition area for the largest regional ports: Krakow, Gdansk, Katowice, Wroclaw and Poznan,

- the third one which forms ports in Bydgoszcz, Lublin, Lodz, Rzeszow, Szczecin and Zielona Gora.

\section{Competitiveness of entities in the air transport sector}

Competitiveness is related to the assessment of the company's performance and its ability to achieve positive results in the future, in particular, profit from its business activities in a variable business environment.

Airport operators, airports, handling companies operate in the liberalized air transport market, but their activities are certified. Although operators have the freedom to operate, they use the instruments of competition, given their participation in servicing the Polish market, it can be seen that this is not a perfectly perfect market. One of the instruments that assess the degree of competition is the concentration factor and the Herfindahl-Hirschman index. The 
Herfindahl Index, as well as the level of competition, is an instrument which determines the level of business congestion in the air transport market. ${ }^{2}$.

Tab. 2. Concentration factor and Herfindahl index for the Polish air transport services market in 2015. Source: based on ULC data.

\begin{tabular}{|c|c|c|c|c|}
\hline \multirow{2}{*}{ Years } & \multicolumn{2}{|c|}{ Concentration factor in\% } & \multicolumn{2}{c|}{ Herfindahl index[pt] } \\
\cline { 2 - 5 } & Carriers & Airports & Carriers & Airports \\
\hline 2015 & 80,44 & 72,77 & 1925 & 1954,27 \\
\hline
\end{tabular}

This situation shows the focus of the transport market around the four largest carriers. On the other hand, the reduction in the concentration coefficient of the sector and the Herfindahl index for airports is indicative of the increasing activity of small regional airports. When analyzing the competitiveness potential of entities representing air transport, two areas of research should be identified: carriers and airports. Given the limited volume, the proposal will cover the entire air transport sector. When analyzing the components of competitiveness potential for the air transport sector, five key factors were identified: innovation, production, marketing, financial policy and organization of the business.

Innovation

Air transport is seen as a vehicle for new technologies, incentives for capital investments, and as an element of innovation in the technical and technological dimension. The main objective of the innovation policy with regard to the air transport market is to increase the competitiveness of businesses, thereby improving the quality of life of society and the quality of the environment and increasing the level of security in the air transport sector $^{3}$.

Technically, it is necessary to indicate the purchase of Boeing 787 "Dreamliner" aircraft by PLL LOT. The Polish carrier estimates that since the launch of the aircraft, it has saved several million zlotys due to lower fuel consumption, which makes it possible to offer services at lower prices. Another technological innovation is the implementation of the baggage transport system at Gdansk Airport. Such solutions have been used only at several European airports. The implementation of this system has practically eliminated the mistakes of erroneous delivery onboard the aircraft, which in the future will limit the number of complaints about lost baggage in the port of Gdansk. With the development of computer science, multimodal applications are playing an increasingly important role, offering not only the opportunity to purchase a ticket, but also receive valuable information about passenger behavior at airports. Passengers who use tablets, smartphones log in to specific terminal access points, provide information about their location, informing the airport about which shopping and food service points were visited, and at what time. Takie informacje mogą być The basis for negotiating the terms of cooperation between the stakeholders. In Poland, specialized companies already offer access points to airports. In addition to innovations, the

\footnotetext{
${ }^{2}$ Herfindahl index is defined by the formula: $H I=10000 \sum_{n=1}^{\infty} S_{i}^{2}$, where $S_{i}$ means market share, more broadly: H. Mruk, Analiza rynku, PWE, Warszawa 2003, p. 246.

${ }^{3}$ D. Tłoczyński, Konkurencja na polskim rynku usług transportu lotniczego, Wyd. Uniwersytetu Gdańskiego, Gdańsk 2016, p. 263-264.
} 
STMS system should be included. It is a complement to the current scheduling system from regional airports and General Aviation. The implementation of STMS is also important for the local community. The system is likely to increase accessibility to large airports for residents of the north-eastern part of Poland (Mazury Airport was opened in 2016) ${ }^{4}$.

\section{Production}

With regard to air transport, production mainly relates to the business model of the functioning of the air transport market. Air carriers offer their passengers varied travel classes, but above all the variety of packages of additional services to the main transport service. A passenger has the option of not only carrying luggage but also how to cancel or move the trip. Passengers are also offered insurance and the possibility of transfer to and from the city center.

The scope of production also includes the state and quantity of equipment to maintain safe air traffic. Only in some ports do carriers have access to technical facilities. Another element of the sphere of production is the technical culture, knowledge, and capabilities of the engineering staff as well as the degree of computerization of logistics processes at airports. In addition, it should be noted that: access to sources of supply, cooperation with suppliers and a system of interconnections.

\section{Marketing}

The factors influencing the competitiveness potential of marketing are:

- aviation budget for marketing activities,

- a diversified strategy for the implementation of marketing mix-instruments,

- implementation of primary and secondary marketing research,

- analysis of passenger needs and behaviors,

- accurate segmentation of the market,

- creativity and ability to plan new, unconventional activities by marketing people,

- development of quality management policy,

- cooperation between all entities related to air transport.

The most important task of marketing policy is to adapt the offer to each market segment and the ability to respond quickly to changing market conditions. Access to certain information, speed of response and skillful implementation of the planned response to the situation lead to a short-term contribution to building the competitiveness potential.

\section{Financial policy}

Competitiveness potential is created by:

- corporate financial policy,

- the level of fixed, total, variable costs,

- the level of direct and indirect costs,

- the level of material and non-material costs,

- access to external sources of finance,

- budgeting possibilities,

- application of the management accounting system,

- use of revenue management, yield management,

- knowledge and ability of financial and accounting services,

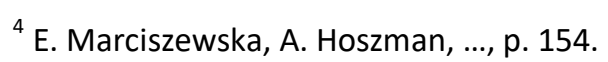


- degree of computerization of the financial and accounting department ${ }^{5}$.

\section{Organization of the operation of the enterprise}

The main elements affecting:

- market share,

- model of business activity,

- ownership relations,

- organization of work and team management skills,

- transparent structure of the company,

- having a short- and long-term strategy,

- how to communicate with company employees,

- integration and motivation of the team, employees,

- cooperation with other aviation and non-aviation operators,

- knowledge of the strengths and weaknesses of competitors,

- implementation of operating systems,

- opportunity to take risks,

- implementation of logistic processes,

- ability to identify future market trends,

- ability to implement theoretical concepts in business practice.

From the factors mentioned above, the vast majority are intangible. This means that in the process of analyzing the competitiveness of air transport sector players play an intangible component of the competitiveness potential.

\section{Road and time availability issues as an element of the competitiveness potential of the air transport sector}

EU standards establish the maximum travel time to the airport for $1.5 \mathrm{hrs}$. In Poland, it takes 2 hours. Taking into account investments in road and rail infrastructure implemented in the last few years, this has resulted in an increase in the impact of the airport, catchment area.

\footnotetext{
${ }^{5}$ M.J. Stankiewicz, Konkurencyjność..., p. 121-122.
} 


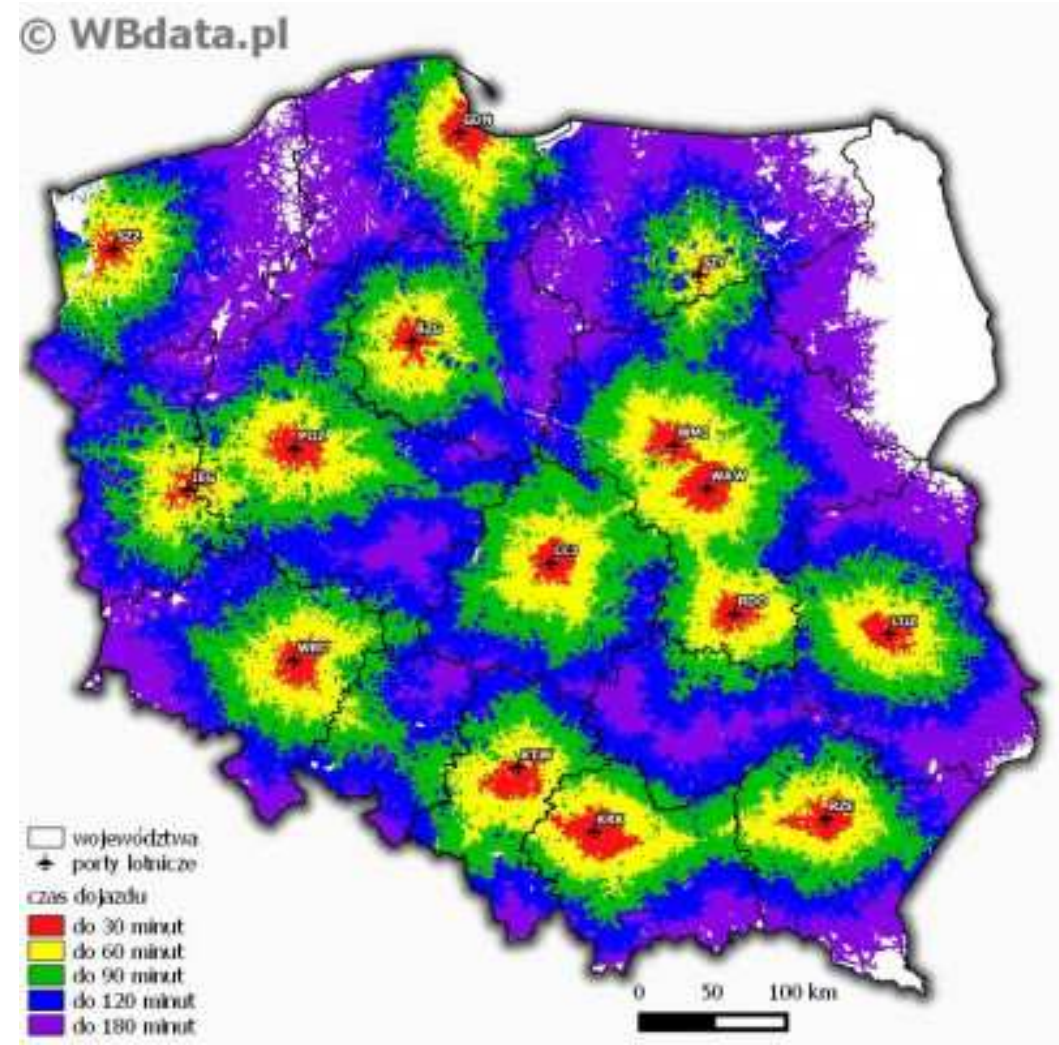

4. Time availability of Polish airports. Source: www.wbdata.pl (access: 13-10-2016).

The availability of air transport in the Warminsko-Mazurskie province has increased in the beginning of air operations at Szymany Airport in 2016. At present, the only province with the longest access to the airport is the Podlaskie province. The two-hour isochronization for Warsaw consists of four airports: F. Chopin, Modlin, Lodz and Radom.

Based on the time of travel to airports, wbdata.pl has designated their areas of accessibility, i.e. the areas with the shortest travel time (closest point). The nearest closest point has a port in Szymany, while the majority of people live in the area of Katowice Airport (almost 5 million) and Okecie (slightly over 4 million). 


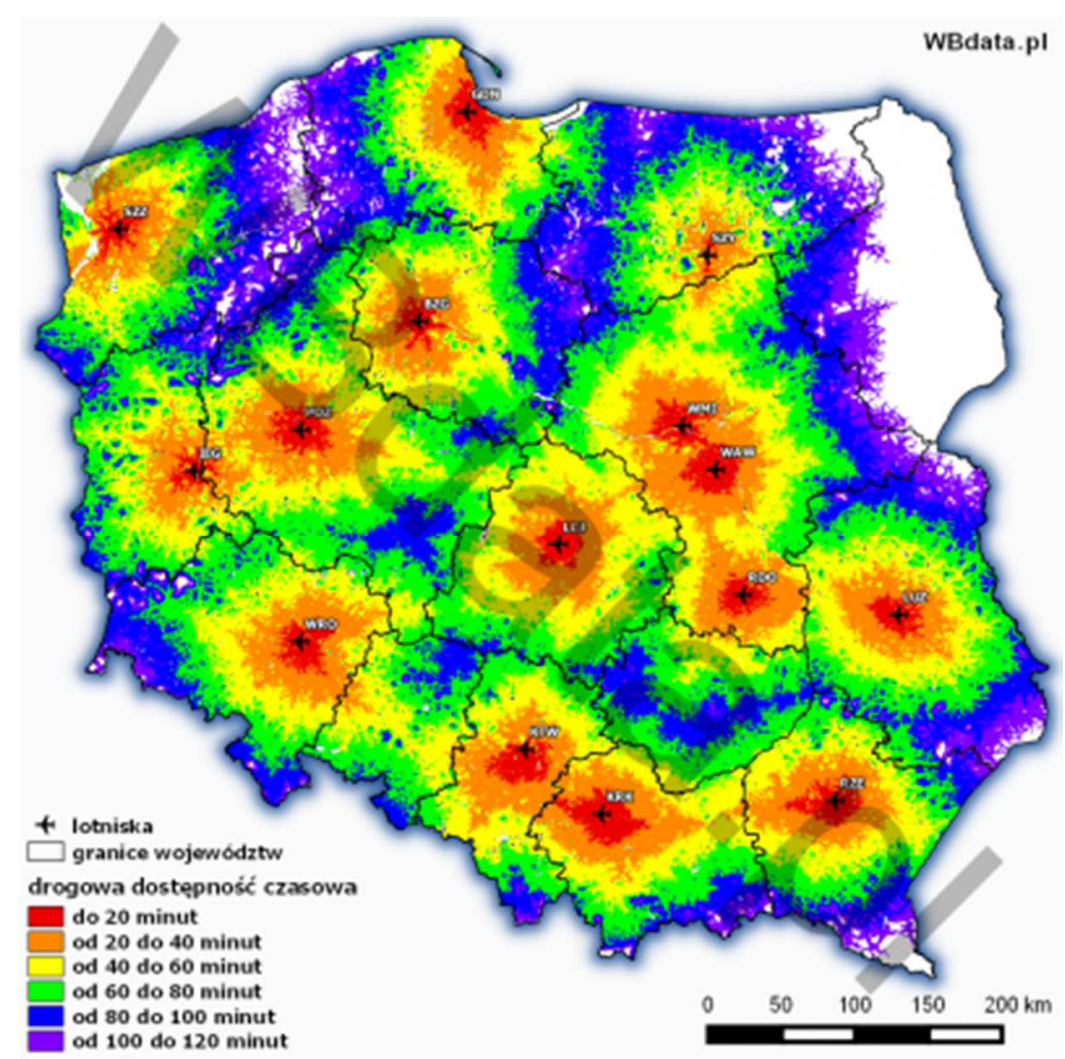

5. Road accessibility to Polish airports. Source: www.wbdata.pl (access: 13-10-2016).

The highest percentage of people in the hour zone from the airport live in the Lodzkie, Slaskie and Mazowieckie provinces (over $80 \%$ ), while in Podlaskie province the percentage is $0.01 \%$. In turn, almost $68 \%$ of the area is located within an hour's distance from the airport. In addition, over $60 \%$ of the area is located in the Silesian, Malopolskie, and Mazowieckie provinces. Least in Podlaskie province. In the two-hour zone of access to the airport, most inhabitants of all the inhabitants of the given province ${ }^{6}$.

\section{Summary}

In conclusion, the research conducted on secondary sources should state that:

- the competitiveness of enterprises plays an important role in order to achieve a competitive advantage,

- Air transport is strongly dependent on the economy of the region, country or the world, and at the same time the economy is strongly linked to air transport,

- airports are generating a large number of jobs,

- there are three groups of airports on the Polish air transport market depending on GDP per capita,

- the Polish air transport service market is concentrated around the four largest air carriers. On the other hand, the smaller Herfindahl index for airports shows the increasing activity of small regional airports,

- cy analyzing the components of competitiveness potential for the air transport sector, five key factors were identified: innovation, production, marketing, financial policies and organization of the business,

\footnotetext{
${ }^{6}$ www.wbdata.pl (access: 12-10-2016).
} 
- the vast majority of factors are intangible. This means that in the process of analyzing the competitiveness of air transport sector players play an intangible component of the competitiveness potential,

- investments in rail and road infrastructure and purchase of Pendolino trains have increased the impact of airports.

The above conclusions lead to the confirmation of the research thesis that an efficient delivery and return system to airports is an important element in building the competitiveness potential of air transport companies.

\section{Source materials}

[1] Bartnicka M., Kompetencje przedsiębiorstwa. Od określenia kompetencji do zbudowania strategii, Agencja Wydawnicza „Placet”, Warszawa 2000.

[2] Bossak J., Międzynarodowa konkurencyjność gospodarki i przedsiębiorstwa. Zagadnienia teoretyczne i metodologiczne [w:] Konkurencyjność gospodarki Polski w dobie integracji z Unią Europejską i globalizacji, pod red. J. Bossaka i W. Bieńkowskiego, t. I, Szkoła Główna Handlowa w Warszawie, Warszawa 2001.

[3] Economic Impact of European Airports. A Critical Catalyst to Economic Growth. ACI Europe, styczeń 2015.

[4] Godziszewski B., Potencjał konkurencyjności przedsiębiorstwa jako źródło przewag konkurencyjnych i podstawa stosowanych instrumentów konkurowania [w:] Budowanie potencjału konkurencyjności przedsiębiorstwa, pod red. M.J. Stankiewicza, Towarzystwo Naukowe Organizacji i Kierownictwa, Toruń 1999.

[5] Marciszewska E., Hoszman A., System transportu matymi samolotami w Polsce założenia modelowe $i$ koncepcja funkcjonowania. [w:] Innowacje w transporcie. Organizacja i zarzadzanie, pod red. P. Niedzielskiego i R. Tomanka, Zeszyty Naukowe Uniwersytetu Szczecińskiego nr 602, Problemy Transportu i Logistyki nr 12, Wyd. Uniwersytetu Szczecińskiego, Szczecin 2010.

[6] Marciszewska E., Kaliński D., Port lotniczy jako czynnik rozwoju regionalnego. [w:] Rozwój lotnictwa w regionach, pod red. A. Barskiego, W. Fabirkiewicza, Cz. Jarosza. Wyd. A. Marszałek, Toruń 2009.

[7] Mruk H., Analiza rynku, PWE, Warszawa 2003.

[8] Raport o polskich metropoliach, PWC, Warszawa 2015.

[9] Stankiewicz M.J., Konkurencyjność przedsiębiorstwa. Budowanie konkurencyjności przedsiębiorstwa $w$ warunkach globalizacji, Towarzystwo Naukowe Organizacji i Kierownictwa, Toruń 2002.

[10] Tłoczyński D., Konkurencja na polskim rynku usług transportu lotniczego, Wyd. Uniwersytetu Gdańskiego, Gdańsk 2016.

[11] www.ulc.gov.pl

[12] www.wbdata.pl 